\title{
CYP2D6*16 Allele
}

National Cancer Institute

\section{Source}

National Cancer Institute. CYP2D6*16 Allele. NCI Thesaurus. Code C46049.

Human CYP2D6*16 allele, located in the vicinity of $22 q 13.1$, is a variant form of the CYP2D6 wild-type allele and encodes cytochrome P450 2D6*16 protein. The CYP2D6*16 allele, resulting from large deletions in the CYP2D gene cluster, is a hybrid consisting of exons 1-7 of the CYP2D7P-related gene and exons 8-9 of the CYP2D6 gene.

Cytochrome $\mathrm{P} 450$ 2D6*16 protein is enzymatically inactive. 